\title{
An energy-friendly alternative in the large-scale production of soybean oil
}

Weibin Kong ${ }^{1}$, Jan Baeyens ${ }^{2}$, Kjerstin De Winter ${ }^{3}$, Andrés Reyes Urrutia ${ }^{4}$, Jan Degrève ${ }^{3}$, Huili Zhang ${ }^{1, *}$

${ }^{1}$ School of Life Science and Technology, Beijing University of Chemical Technology ${ }^{2}$ Beijing Advanced Innovation Centre for Smart Matter Science and Engineering, Beijing University of Chemical Technology

${ }^{3}$ KULeuven, Faculty of Engineering Science, Department of Chemical Engineering ${ }^{4}$ PROBIEN,Universidad Nacional del Comahue, Neuquén, Argentina Corresponding author: Huili Zhang, zhhl@mail.buct.edu.cn

\section{ABSTRACT}

Soybean oil is widely used as cooking oil, whereas the soybean cake is a valuable ingredient for animal food. The extraction of soybean oil is an energy-intensive process, with additional significant impact on the environment via the wastewater and hexane emissions. The result investigated different ways to minimize the energy consumption. In a traditional process, both direct (live) steam and indirect steam heating (jackets, tubular exchangers) are used to deliver the required heat duty. Direct steam injection is restricted to the first evaporator and the stripper, for a total of $620 \mathrm{~kg} / \mathrm{h}$. Indirect steam is also applied in the evaporators for a total of $6.44 \mathrm{MW}$. The desolventizing process requires a steam energy input of 8.15 MW. Integration of a heat exchanger network in the evaporation and stripping part of the process reduces the amount of direct steam usage from $620 \mathrm{~kg} / \mathrm{h}$ to $270 \mathrm{~kg} / \mathrm{h}$ and of the indirect heat duty from 6.44 to $5.05 \mathrm{MW}$. In the cake desolventizing part of the process, the energy requirement is reduced from 8.15 to $2.12 \mathrm{MW}$. The overall gross energy saving is hence $\sim 50 \%$. The improvements moreover reduce both the waste water loadings by $56.5 \%$ and the $\mathrm{CO}_{2}$ emissions by 62.5 . Hexane emissions are moreover significantly $(>90 \%)$ reduced.

Keywords: Soybean oil, extraction, heat recovery, fluidized bed, hexane recovery, devolatilisation

\section{INTRODUCTION}


Vegetable oils are commonly used for different end applications. Whereas edible vegetable

\begin{tabular}{cc}
\hline Component & Percentage (\%) \\
\hline Alpha- linoleic acid (polyunsaturated) & $7-10$ \\
Linoleic acid (polyunsaturated) & 51 \\
Oleic acid (monounsaturated) & 23 \\
Stearic acid (saturated) & 4 \\
Palmitic acid (saturated) & 10 \\
\hline
\end{tabular}

oils, such as soybean, peanut, palm and sunflower oils are used in food commodities. (Alam et al., 2014), they also find applications in biodiesel or even bio-aviation fuel via trans-esterification and other secondary transformation processes. (Issariyakul and Dalai, 2014; Lin et al., 2009; Wang et al., 2017; Yun et al., 2013). There are also a number of oils, such as rice bran oil, palm kernel oil and sheanut butter, that are used in specific markets with added value for cosmetics and pharmaceuticals. (Cargill, n.d.)

Soybeans are used worldwide for their oil and protein contents. In 2017, the world production of soybeans was 340 million ton (33.9\% in America, 32.1\% in Brazil, $16.2 \%$ in Argentina). The world production of soybean oil was 56 million ton. The high content of poly-unsaturated components in soya has positive effects on the human health, by e.g. reducing the blood lipids, preventing blood clots, and boosting immunity. The cultivation of soybeans moreover captures nitrogen from the air and transforms it into $\mathrm{N}$-fertiliser. The main components of the soybean are proteins (36 wt $\%)$, carbohydrates (30 wt $\%)$, fat/oil (20 wt $\%)$ and water $(9 \mathrm{wt} \%)$. The composition of the soybean oil is given in Table 1. (Carrín and Crapiste, 2008)

Table 1 Composition of soybean oil
47

\footnotetext{
After an extraction with hexane, two streams are produced, i.e. a liquid phase (miscella: soybean oil and n-hexane) and a residual solid phase (soybean cake containing hexane).

The oil cake consists of proteins and carbohydrates. Soybean meal is produced from the oil cake after removing and recovering hexane. Animal feed is the main application for this meal (98\%), where it is very popular for its low price, high protein content, and exceptional source of essential nutrients. During the pretreatment of the soybeans, high temperatures can cause
} 
denaturation of some proteins, and thus a loss of functionality. (Cerutti et al., 2012).

In earlier papers, Kong et al. (Kong et al., 2018, 2017a) studied the extraction and treatment processes for a small-scale Rice Bran Oil (RBO) plant. Several measures of energy reduction were investigated and a novel devolatilization method of the cake using nitrogen was introduced and experimentally studied. The present research expands these findings to a large-scale soybean oil process, with special emphasis on the improved energy efficiency and on the pollution prevention as a result of the process improvements.

\section{DESCRIPTION OF THE TRADITIONAL PROCESS}

As previously detailed by Kong et al., (Kong et al., 2018) there are two main methods for producing vegetable oils, either by pressing or extrusion at small to moderate capacities, or by solvent extraction of the pretreated oil seeds when larger capacities are needed. The solvent for extraction is usually hexane, and the first stages of extraction can use a mixture of solvent (hexane) and oil is often used, called miscella. Figure 1 illustrates the conventional setup for the extraction of soybean oil (SBO). The oil production process for different oil seeds is quite similar and typically consists of the following steps. First the oilseeds are delivered, and a pretreated (drying, dehulling, flaking). Subsequently the actual leaching process takes place. Crude SBO is extracted on a belt conveyor by hexane. This is followed by the removal of hexane from both the miscella and from the cake. The miscella is subjected to a two-step evaporation and a direct steam stripping. Soybean meal is thermally treated in a multiple hearth desolventizer/toaster/cooler. Solvent and water vapors are then condensed in a multi-step cooling. Residual vapors are finally stripped of hexane by absorption in paraffin. Hexane is recovered and can be reused in the leaching process. (Martinho et al., 2008) 


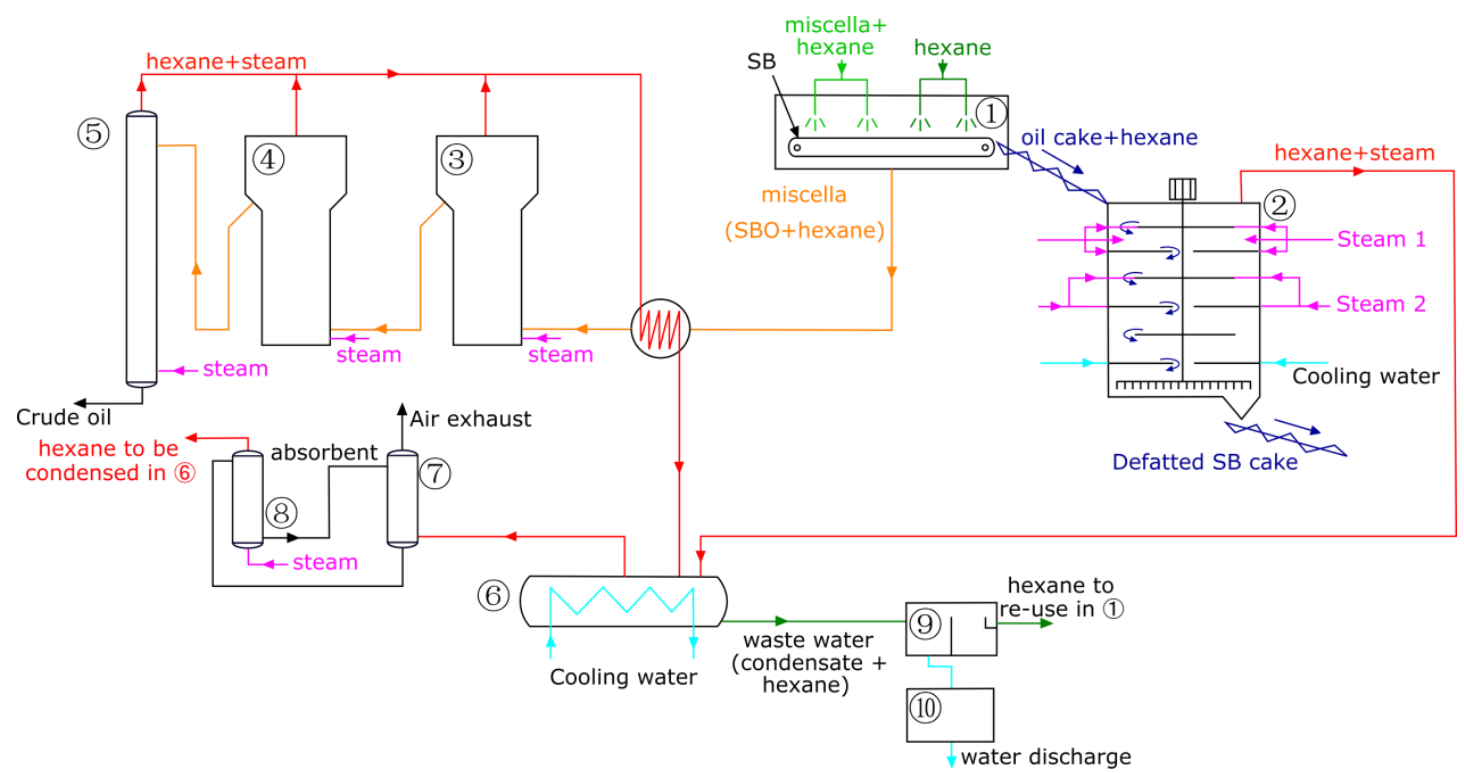

Figure 1. Traditional SBO solvent-extraction: (1) Leaching (2) Desolventizer/toaster/cooler, (3) $1^{\text {st }}$ evaporator, (4) $2^{\text {nd }}$ evaporator, (5)stripping tower, (6) cooler, (7) absorption (8), desorption, (9) water/hexane separator, (10) waste water treatment plant. Steam 1 is indirect or direct steam for hexane volatilisation, Steam 2 is indirect steam for toasting

The process is very energy intensive by the large amount of steam and cooling water needed, mainly in the solvent removal/recovery sections of the process. In addition, the supply and storage of hexane as well as diffusive losses from the waste water treatment, pipes, pumps, valves and vents create considerable atmospheric emissions of hexane. The waste water still contains trace quantities of hexane $(<0.2 \mathrm{vol} \%$ and $<0.014 \mathrm{vol} \%$ respectively). At the end of the process, solvent free products must remain. Reductions in steam and cooling water consumptions as well as reducing the environmental effects of the process are important economic targets in improving solvent extraction plants. In order to meet these objectives, the present paper investigates possible methods to improve the traditional process by: (i) examining and minimizing the steam and heat duty requirements in the evaporator-stripper part of the extraction process by performing a sensitivity analyses in Aspen Plus ${ }^{\circledR}$ V8.2; (ii) assessing a further reduction of the energy requirements by replacing steam by nitrogen in an alternative oil cake desolventizing process; and (iii) examining the environmental benefits of the process improvements.

\section{ENERGY SAVING SIMULATIONS AND METHODS}




\section{Characteristic}

Temperature $\left({ }^{\circ} \mathrm{C}\right)$

Pressure (bar)

Occurring Phases

Table 2 Configuration of both evaporators (Kong et al., 2015b)

\subsection{Process description and operating parameters}

The previous studies by Kong et al. for the RBO case study show that simulations using Aspen Plus ${ }^{\circledR}$ V8.2 provides results which approach the real process. (Kong et al., 2018, 2017a, 2015a) The same simulations will therefore be used to obtain the steam requirements for the extraction of soybean oil (SBO), operated in a similar process as for RBO. In the RBO-study, the capacity was $1,330 \mathrm{~kg} / \mathrm{h} \mathrm{RBO}$. The entire process is scaled to the desired capacity of SBO $(10,000$ $\mathrm{kg} / \mathrm{h}$ ), keeping the same temperatures and pressures of the streams/bloc elements. The set-up of the three oil-hexane columns can be seen in Figure 2, with essential parameter data given in Table 2.

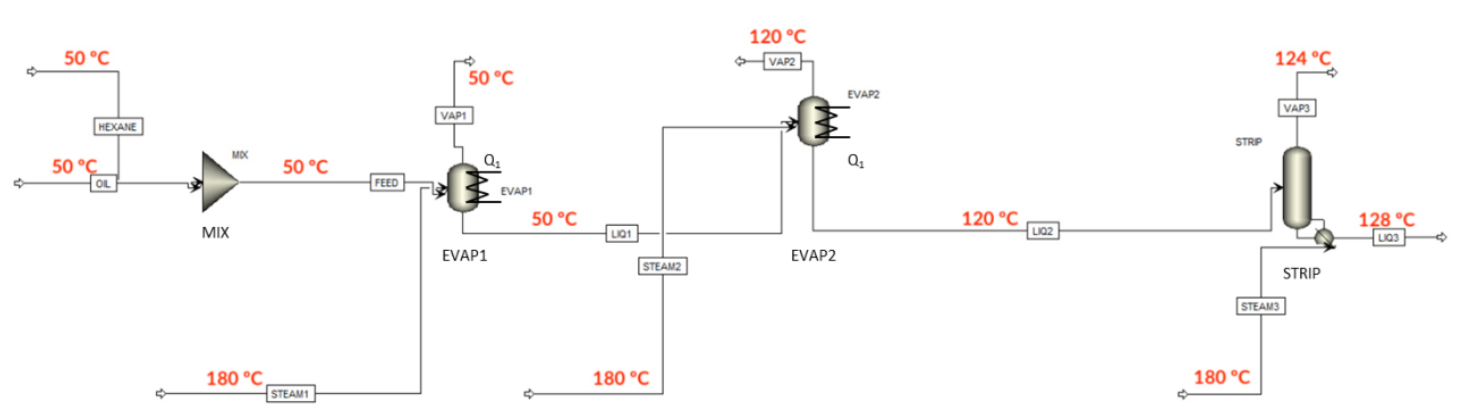

113 hexane (HEXANE). The composition of OIL is given in Table 1. The mass flow of this stream is

$11410,000 \mathrm{~kg} / \mathrm{h}$. To achieve a complete oil leaching, the maximum mass flow rate of hexane should be

$11541,308 \mathrm{~kg} / \mathrm{h}$. Both streams have a temperature of $50{ }^{\circ} \mathrm{C}$, a pressure of $1 \mathrm{~atm}$, and are mixed at these conditions. Saturated steam is available at 10 bar and $179.9^{\circ} \mathrm{C}$.

To simulate the evaporators, the block Flash2 is chosen. The choice to keep the evaporators at

118 a constant temperature ensures that not all of the used steam condenses and dilutes the product 
stream. Keeping the second evaporator at $120{ }^{\circ} \mathrm{C}$ also ensures that the vapor stream from this column is usable for heat recovery. To keep these columns at their desired temperature, they require an input of energy. These heat duties are mostly provided by steam in an external jacket. No loss of energy to the environment is assumed.

The stripping column can be configured as a RadFrac type. It has only two stages and neither reboiler nor condenser. At the first stage, LIQ2 enters and VAP3 leaves; at the second stage STEAM3 enters and LIQ3 leaves. No pressure drop is assumed across the stages, thus maintaining a constant pressure of $0.5 \mathrm{bar}$ and operated around $120^{\circ} \mathrm{C}$, which is the temperature of the liquid input. If heat exchangers are used in further flow sheets, they are set-up with countercurrent flow and with a minimum temperature difference of $10{ }^{\circ} \mathrm{C}$ between the hot outlet flow and cold inlet flow. Non-Random Two-Liquids - Redlich-Kwong (NRTL-RK) is used in Aspen Plus ${ }^{\circledR}$ as the main method throughout the simulations. For the water phase, the Steam Tables are consulted by the simulation program.

There are three directly injected steam flow rates that need to be calculated with Aspen Plus ${ }^{\circledR}$, one for each column and indicated as STEAM1, STEAM2 and STEAM3 in Figure 2. The indirect heating of EVAP1 and EVAP2, indicated as Q1 and Q2 respectively, complete the required heat duty. Simultaneously varying the mass flow rates of the three live steam additions is not an efficient strategy and will significantly complicate the calculation. Therefore, the calculations are split into two parts: the first part considers both evaporators while afterwards the stripping column is taken into account.

Because the goal is to design a process that has minimum energy requirements, the heat duties of the evaporators have to be taken into account on the basis of the required energy to produce steam. Steam at $10 \mathrm{bar}$ has a specific enthalpy of 2,778 $\mathrm{kJ} / \mathrm{kg}$. (Spirax Sarco, 2018) and is produced in a boiler, starting from condensate and make-up water at a pressure of 10 bar and a temperature of $25{ }^{\circ} \mathrm{C}$. This water has a specific enthalpy of $105 \mathrm{~kJ} / \mathrm{kg}$. The net steam duty is hence $2673 \mathrm{~kJ} / \mathrm{kg}$. If the efficiency of the boiler is taken at 85 to $90 \%$, the gross energy required to produce $1 \mathrm{~kg}$ of steam can be calculated:

$$
\Delta h_{\text {boiler }}=\left(h_{\text {steam }}-h_{\text {water }}\right) / \eta_{\text {boiler }}=2673 / 0.85 \text { or } 0.9=3145 \text { or } 2970 \mathrm{~kJ} / \mathrm{kg}
$$

$$
\text { The required energy to operate the two evaporators consists of the indirect heat duties }(Q 1
$$
$[M W]$ and $Q 2[M W])$ and the live steam injection $\left(m_{\text {STEAMI }}[\mathrm{kg} / \mathrm{h}]\right.$ and $\left.m_{\text {STEAM2 }}[\mathrm{kg} / \mathrm{h}]\right)$ : 


$$
E_{\text {evap }}=Q_{1}+Q_{2}+\Delta h_{\text {boiler }} \times \frac{m_{\text {STEAM } 1}+m_{\text {STEAM } 2}}{3600 \mathrm{~s} / \mathrm{h}}
$$

Equation 2 has to be minimized, while also meeting the hexane content guideline from Table

3. The flow rates of STEAM1 $\left(m_{S T E A M 1}\right)$ and STEAM2 $\left(m_{\text {STEAM2 }}\right)$ are varied both from 0 to 500 $\mathrm{kg} / \mathrm{h}$ at an interval of $50 \mathrm{~kg} / \mathrm{h}$ (11 different values), thus creating $121\left(11^{2}\right)$ different possible combinations.

Table 3: Hexane content guidelines for different streams

\begin{tabular}{ccc}
\hline Stream & RBO extraction (Kong et al., 2015b) & SBO extraction \\
\hline FEED & $4,122-5,494 \mathrm{~kg} / \mathrm{h}$ & $30,992-41,308 \mathrm{~kg} / \mathrm{h}$ \\
LIQ1 & $587-913 \mathrm{~kg} / \mathrm{h}$ & $4,413-6,864 \mathrm{~kg} / \mathrm{h}$ \\
LIQ2 & $<70 \mathrm{~kg} / \mathrm{h}$ & $<526 \mathrm{~kg} / \mathrm{h}$ \\
LIQ3 & $<4 \mathrm{~kg} / \mathrm{h}$ & $<30 \mathrm{~kg} / \mathrm{h}$ \\
\hline
\end{tabular}

153

After the optimum combination of $m_{S T E A M 1}$ and $m_{S T E A M 2}$ is selected using Equation 2, the flow rate of the steam going into the stripper ( $\left.m_{\text {STEAM3 }}\right)$ where only live steam is injected. The flow rate is varied from 100 to $500 \mathrm{~kg} / \mathrm{h}$, for intervals of $10 \mathrm{~kg} / \mathrm{h}$. The criterion to select the optimal $m_{S T E A M 3}$ is that the liquid outflow of the stripping column must contain less than $30 \mathrm{~kg} / \mathrm{h}$ of hexane, while minimizing the amount of steam used. This stripper has no indirect heat duty to be taken into account.

\subsection{Results and discussion}

\subsubsection{Energy consumption of the traditional process}

The FEED contains $41,308 \mathrm{~kg} / \mathrm{h}$ hexane. After the two evaporators, this has to be reduced to approximately $526 \mathrm{~kg} / \mathrm{h}$. The sensitivity analysis consists of 121 separate simulations, each with a different configuration of $m_{S T E A M 1}$ and $m_{S T E A M 2}$. Figure 3 displays the configuration results. Configuration $\mathrm{N}^{\circ} 89$ minimizes the energy requirement for the system of two evaporators. The first evaporator uses $400 \mathrm{~kg} / \mathrm{h}$ of steam $\left(m_{\text {STEAMI }}\right)$ and requires $2.30 \mathrm{MW}$ of additional external heating $(Q 1)$. The second evaporator uses no direct steam and requires $2.71 \mathrm{MW}$ of additional heating $(Q 2)$. The liquid that exits the second evaporator to the stripping contains $434.3 \mathrm{~kg} / \mathrm{h}$ of hexane, which is well below the guideline of Table 3. Using Equation 2, a net total energy requirement of 5.30 MW 
171 for the two evaporators is calculated. Using this optimal configuration for EVAP1 and EVAP2, a 172 sensitivity analysis for $m_{S T E A M 3}$ is performed. The liquid output of the stripping column has to contain less than $30 \mathrm{~kg} / \mathrm{h}$ of hexane as a strict requirement. The results for the several values of $m_{S T E A M 3}$ are represented in Figure 4.

(a)

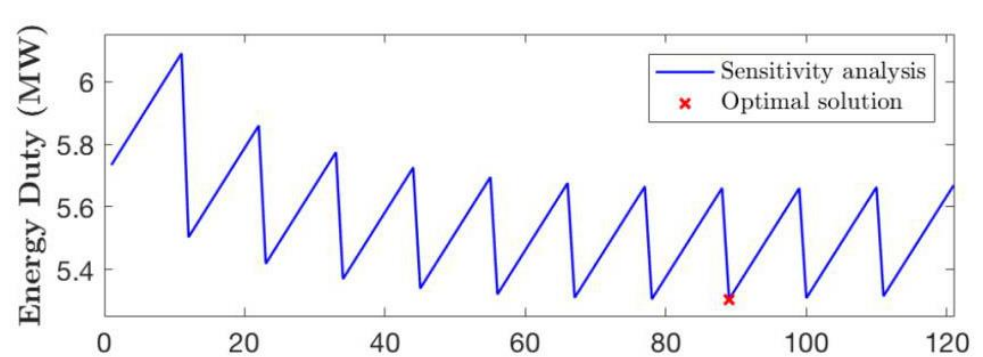

175

176

177

178

179

180

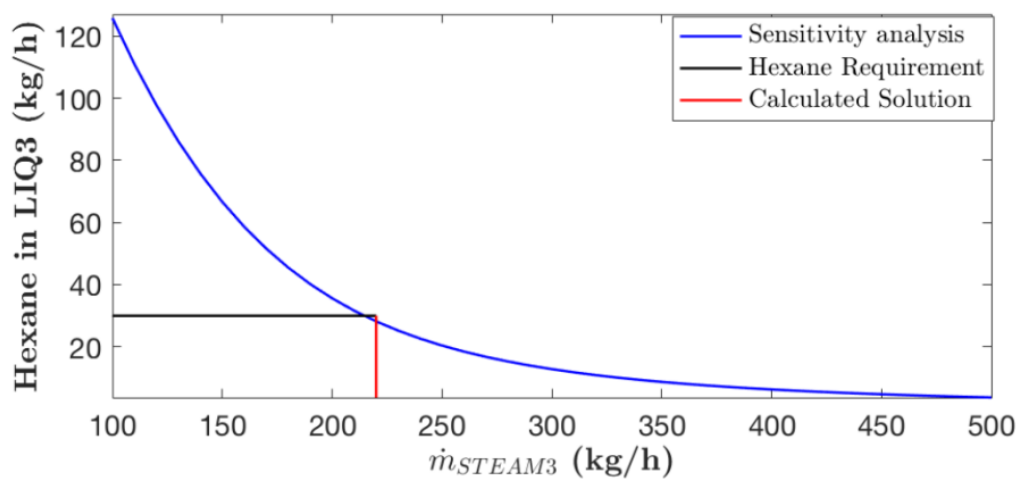

Figure 4: Hexane remaining in the liquid outflow of the stripper for different values of $m_{\text {STEAM3 }}$

The minimum amount of steam that is needed to meet the stripper requirement is $220 \mathrm{~kg} / \mathrm{h}$. This results in a liquid outflow that contains $28.2 \mathrm{~kg} / \mathrm{h}$ of hexane, $133.3 \mathrm{~kg} / \mathrm{h}$ of water and 9,996 $\mathrm{kg} / \mathrm{h}$ of SBO. This stream has a temperature of $128^{\circ} \mathrm{C}$, which could be used for heating a colder 
stream.

\subsubsection{Heat exchange improvements of the traditional process}

Within the traditional process, there are different options to improve the energy efficiency by adding waste heat exchangers into the circuits. These different options are illustrated in Figure 5, and involve either adding one heat exchanger (HEX1), or two heat exchangers (HEX2) in two options A and B.

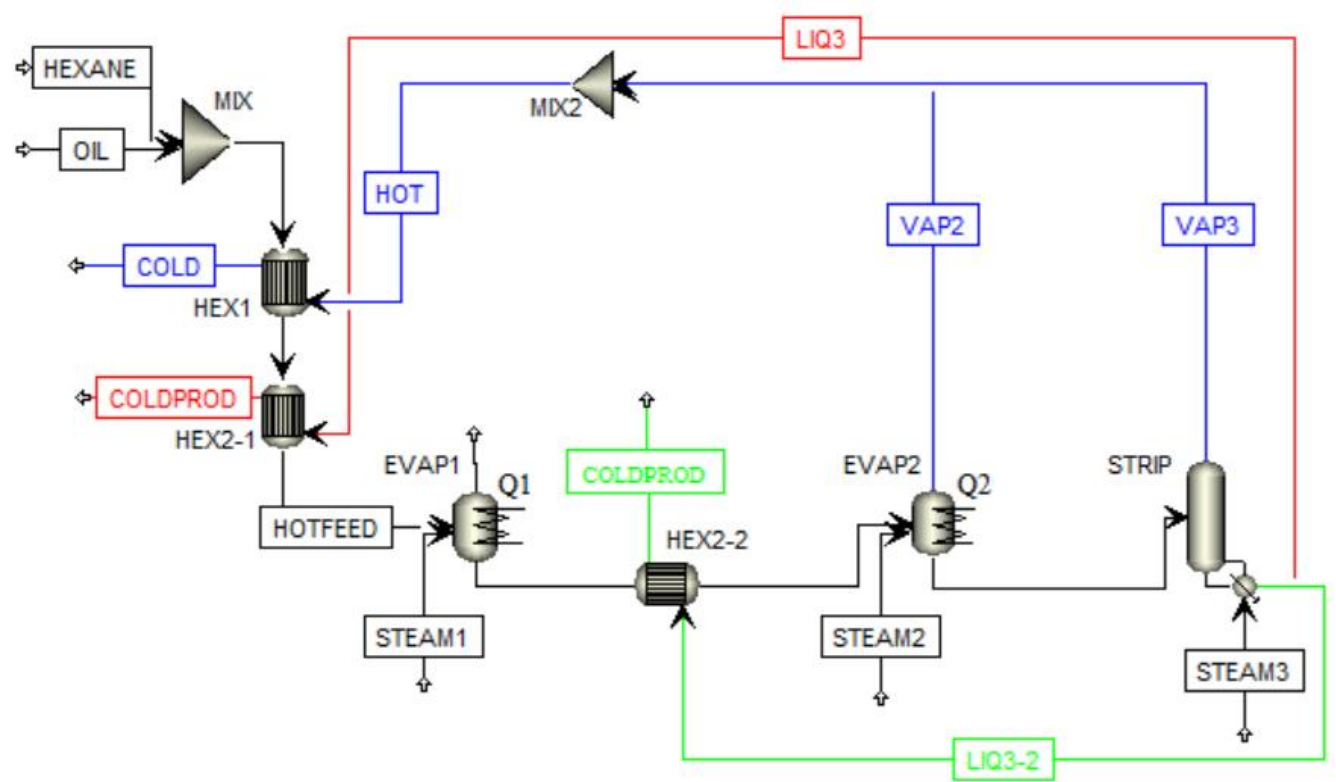

Figure 5 Heat recovery improvements of the conventional extraction process. Red: one heat

\section{One additional heat exchanger}

The vapor streams that exit the second evaporator and the stripping column are both at high temperature $\left(120{ }^{\circ} \mathrm{C}\right.$ and $124{ }^{\circ} \mathrm{C}$ respectively). These two are combined and sent to a heat exchanger that will heat the FEED stream. Figure 5 displays the new flow sheet. A similar sensitivity analysis as presented in section 3.2.1 can be used to optimize the heat recovery efficiency. The energy balance and residual hexane concentration around the stripping column remain unchanged and were presented in Figure 4 before. Results of the simulation are given in Appendix (Figure A1). The first evaporator utilizes $50 \mathrm{~kg} / \mathrm{h}$ of live steam $\left(m_{S T E A M} 1\right)$ and consumes 
two evaporators, the liquid outflow still contains $436.87 \mathrm{~kg} / \mathrm{h}$ of hexane. To reduce this hexane content below $30 \mathrm{~kg} / \mathrm{h}$, the stripper needs at least $220 \mathrm{~kg} / \mathrm{h}$ of steam, as shown in Figure 4. This results in a liquid outflow that contains $27.5 \mathrm{~kg} / \mathrm{h}$ of hexane, $133.8 \mathrm{~kg} / \mathrm{h}$ of water and $9993 \mathrm{~kg} / \mathrm{h}$ of SBO.

\section{Two additional heat exchangers (option A)}

An additional stream is selected to further preheat the feed. The liquid exit flow of the stripper has a temperature of $128{ }^{\circ} \mathrm{C}$ and a mass flow rate of $10,158 \mathrm{~kg} / \mathrm{h}$. This stream, which contains the desired oil product can be used for preheating other streams. Two different streams can be preheated: HOTFEED and LIQ1. This will decrease the heat duty of the evaporators by implementing a second heat exchanger to preheat the feed. This is represented in Figure 5. The sensitivity analysis (Appendix, Figure A2) demonstrates that the first evaporator has a heat duty of $-0.045 \mathrm{MW}$, meaning that there is a limited amount of additional heat available for a recovery. In practice, this heat can be used to preheat the boiler feed water ( of $25^{\circ} \mathrm{C}$ ). The first evaporator uses $50 \mathrm{~kg} / \mathrm{h}$ of steam $\left(m_{S T E A M 1}\right)$. The second evaporator requires $4.26 \mathrm{MW}(Q 2)$ and no live steam. The liquid that exits the second evaporator to the stripping still contains $436.9 \mathrm{~kg} / \mathrm{h}$ of hexane, again below the guideline. This results in a total indirect energy requirement of $4.26 \mathrm{MW}$ for the two evaporators.

The stripper column employs $220 \mathrm{~kg} / \mathrm{h}$ of steam to reduce this hexane content to below 30 $\mathrm{kg} / \mathrm{h}$, according to the sensitivity analysis. This results in a liquid that contains $28.4 \mathrm{~kg} / \mathrm{h}$ of hexane, $133.1 \mathrm{~kg} / \mathrm{h}$ of water and $9,993 \mathrm{~kg} / \mathrm{h}$ of SBO. This stream has a temperature of $128^{\circ} \mathrm{C}$.

COLDPROD is still at a relatively high temperature $\left(81^{\circ} \mathrm{C}\right)$ after leaving the heat exchanger. HOTFEED is only $0.4{ }^{\circ} \mathrm{C}$ hotter than in the previous set-up, but its vapor fraction has increased from $0 \%$ to $12 \%$. The exchanged heat in the second heat exchanger is thus used for the partial evaporation of the feed.

\section{Two additional heat exchangers (option B)}

LIQ3 will be used to preheat LIQ1 before it enters the second evaporator, which is displayed in Figure 5. Results are illustrated in Appendix, Figure A3. Similar to the previous set-ups, the first evaporator now uses $50 \mathrm{~kg} / \mathrm{h}$ of steam $\left(m_{\text {STEAM1 }}\right)$ and has an indirect heat duty of $0.25 \mathrm{MW}$ (in 
contrast to the negative $Q 1$ in option A). The second evaporator solely requires $3.84 M W(Q 2)$ (without live steam addition). A total energy requirement of $4.13 \mathrm{MW}$ is calculated for the first two evaporators. This is less than the energy requirement for the previous set-up. At $220 \mathrm{~kg} / \mathrm{h}$ of steam feed, the stripper column reduces the hexane content from $436.9 \mathrm{~kg} / \mathrm{h}$ to below $30 \mathrm{~kg} / \mathrm{h}$. LIQ3 contains $28.4 \mathrm{~kg} / \mathrm{h}$ hexane, $133.1 \mathrm{~kg} / \mathrm{h}$ and $9,993 \mathrm{~kg} / \mathrm{h}$ oil.

LIQ3 is cooled from $128{ }^{\circ} \mathrm{C}$ to $60{ }^{\circ} \mathrm{C}$, too cold for further heat recovery and COLDPROD thus serves no further use. LIQ1 is heated only from $50{ }^{\circ} \mathrm{C}$ to $51{ }^{\circ} \mathrm{C}$, since most of the exchanged energy is used as latent heat to evaporate the hexane in LIQ1, this explains the small increase in temperature. The vapor fraction of LIQ1 increases from $0 \%$ to $13 \%$.

Although the stream that exits HEX2 can still be further used to preheat LIQ1, the heat recovery potential is limited, and the implementation of an extra heat exchanger is neither thermally nor economically justified.

\section{Final Selection}

The different set-ups that were discussed in the previous sections all have different energy consumptions. Table 4 displays these different values as well as their saved energy relative to the basic set-up. $E_{\text {evap }}$ is calculated using Equation 3. Option 2 (B) has the highest energy saving potential and $21.2 \%$ of the energy can be saved.

$$
E_{\text {evap }}=Q_{1}+Q_{2}+\Delta h_{\text {boiler }} \times \frac{m_{\text {STEAM } 1}+m_{\text {STEAM2 }}+m_{\text {STEAM } 3}}{3600 \mathrm{~s} / \mathrm{h}}
$$

Table 4: Summary of the energy consumption for the five different set-ups

\begin{tabular}{ccccc}
\hline heat exchangers & 0 & 1 & 2 (option A) & 2 (option B) \\
\hline$Q 1(M W)$ & 2.30 & 0.25 & -0.045 & 0.25 \\
$Q 2(M W)$ & 2.71 & 4.26 & 4.26 & 3.84 \\
$m_{\text {STEAM1 }}(\mathrm{kg} / \mathrm{h})$ & 400 & 50 & 50 & 50 \\
$m_{\text {STEAM2 }}(\mathrm{kg} / \mathrm{h})$ & 0 & 0 & 0 & 0 \\
$m_{\text {STEAM3 }}(\mathrm{kg} / \mathrm{h})$ & 220 & 220 & 220 & 220 \\
$E_{\text {evap }}(\mathrm{MW})$ & 5.47 & 4.71 & 4.42 & 4.29 \\
Energy Saved & $0 \%$ & $13.9 \%$ & $19.2 \%$ & $21.2 \%$ \\
\hline
\end{tabular}


256 It should however be remembered that values indicated are net heat duties. Considering the 257 efficiency of the boiler ( $85-90 \%$ ), the gross heat supply to the boiler should be multiplied by $2581 / 0.85$ or $1 / 0.9$ respectively, increasing the amount of fuel to be burned in the boiler.

\section{IMPROVEMENT OF THE DESOLVENTIZER OPERATION}

\subsection{Desolventizer in the traditional process}

To obtain the separation between the oil cake and hexane, the aforementioned desolventizer-toaster (DT) unit is applied. The DT is of multiple-heath concept. To keep the hexane cake mixture moving downwards from tray to tray, there is a rotating central shaft with arms horizontally connected to it. Rotation of the central shaft causes the arms to sweep over the horizontal trays and thus keep the materials moving and stir the mixture. The oil cake-solvent mixture from the extraction process enters the desolventizer-toaster at the top. Steam is used to increase the wet meal temperature and evaporate the hexane and moisture from the oil cake. The steam can be introduced directly and indirectly to the mixture via the trays. One can distinguish between indirect tray steam and live sparge steam heating, the latter using steam directly introduced to the meal via holes in the desolventizing tray or the sweeping arms.

Various articles have investigated the desolventizer and all its aspects, as one of the problems that industry encounters is the high energy requirements. This high energy requirement originates from the production of steam that is used for hexane removal from the meal. Alternative toasting techniques to lower the energy usage in a desolventizer include the mitigation of additional heat that is required for drying of the flakes (Ong, 1984). Using the energy requirement of the pilot $1,330.00 \mathrm{~kg} / \mathrm{h}$ RBO process, an estimation can be made for the $10,000 \mathrm{~kg} / \mathrm{h}$ SBO process. (Kong et al., 2018) On average, the amount of steam needed to desolventize and toast the cake is 0.195 $\mathrm{MW} / \mathrm{kg}$ cake. Depending on the operating steam conditions (pressure, temperature) this results in $265 \mathrm{~kg}$ steam/ton cake for 6 bar saturated steam, and $263 \mathrm{~kg}$ steam/ton cake for 10 bar saturated steam.

Transforming this to the soybean case, with $35,500 \mathrm{~kg} / \mathrm{h}$ of cake produced, and using $10 \mathrm{bar}$ saturated steam, the total amount required is 9.34 ton steam/h or $7.7 \mathrm{MW}$ at a boiler efficiency of $90 \%$. 


\subsection{Fluidized bed desolventizer}

The most promising alternative replaces the live and indirect steam heating of the flakes in the desolventizer by a nitrogen driven fluidized bed. Fluidization is an interesting technique that is already applied in conventional food processing for drying of various solids. Its popularity originates from the high mass and heat transfer achieved in these beds by continuously pumping a gas through different gaps in the distributor plate. This initiates the agitation of the particles present in the bed. As soon as the gas velocity is high enough to carry the weight of the particles (= minimum fluidization velocity), fluidization sets in, which enhances the mixing of solids and results in a uniform temperature throughout the bed.

Experiments have shown that compared to the conventional techniques, a high hexane removal can be achieved with a low residence time $(\tau)$ of the flakes by making use of a fluidized bed desolventizing unit. The usage of nitrogen gas also allows the bed to be operated at a lower temperature compared to the conventional technique. Nitrogen lowers the partial pressure of the hexane which increases the volatility of the compound as can be seen in Figure 6. (Kong et al., 2018) There is however the need for on-site production of nitrogen $(95-99 \%)$ at a medium production capacity. This can be done by installing either a pressure swing adsorption system or a membrane unit. Membrane systems can be useful due to their robustness but often cannot deliver the nitrogen gas capacity needed to sustain the fluidized bed operation. Since most of the $\mathrm{N}_{2}$ is recovered in the desolventizer membrane separation module, only minor flow rates of make-up $\mathrm{N}_{2}$ are required. Hence $\mathrm{O}_{2} / \mathrm{N}_{2}$ membrane separation is the evident choice. 


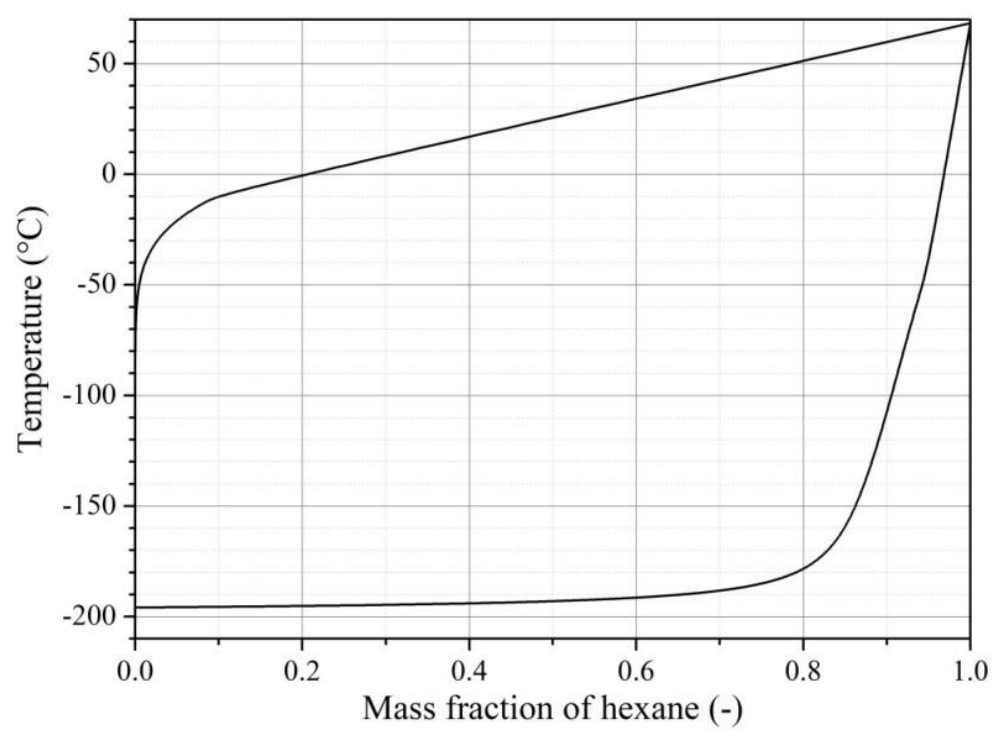

Figure 6: Vapor-liquid equilibrium diagram of the nitrogen-hexane mixture at 1 bar

When applying the fluidized bed as a desolventizer, a constant feed stream is transported 310 from the hexane extractor to the fluidized bed. (Erickson, 1995) Here, heat is provided to the 311 flakes in two ways. First of all heat is transferred in a forced convective way by the high 312 temperature nitrogen gas flowing around the particles. Secondly conductive transport of heat 313 occurs by contacting the particles against the surrounding heated walls. When operating at a bed 314 temperature of $50{ }^{\circ} \mathrm{C}$, the hexane content of the meal is lowered beneath the threshold value of $3150.1 \%$. This value is reached in about 150 seconds (Kong et al., 2018) when the fluidized bed is operated at superficial gas velocities in excess of $0.04 \mathrm{~m} / \mathrm{s}$. There are two exit streams in the fluidization process: the gas exiting the top is a mixture of hexane and nitrogen (which can still be used for the preheating of other streams), and the meal itself, of which the residual heat will be regarded as a heat loss due to the low efficiency and practical difficulty of energy recovery from the low temperature meal. The layout of the fluidized bed desolventizer is illustrated in Figure 7. 


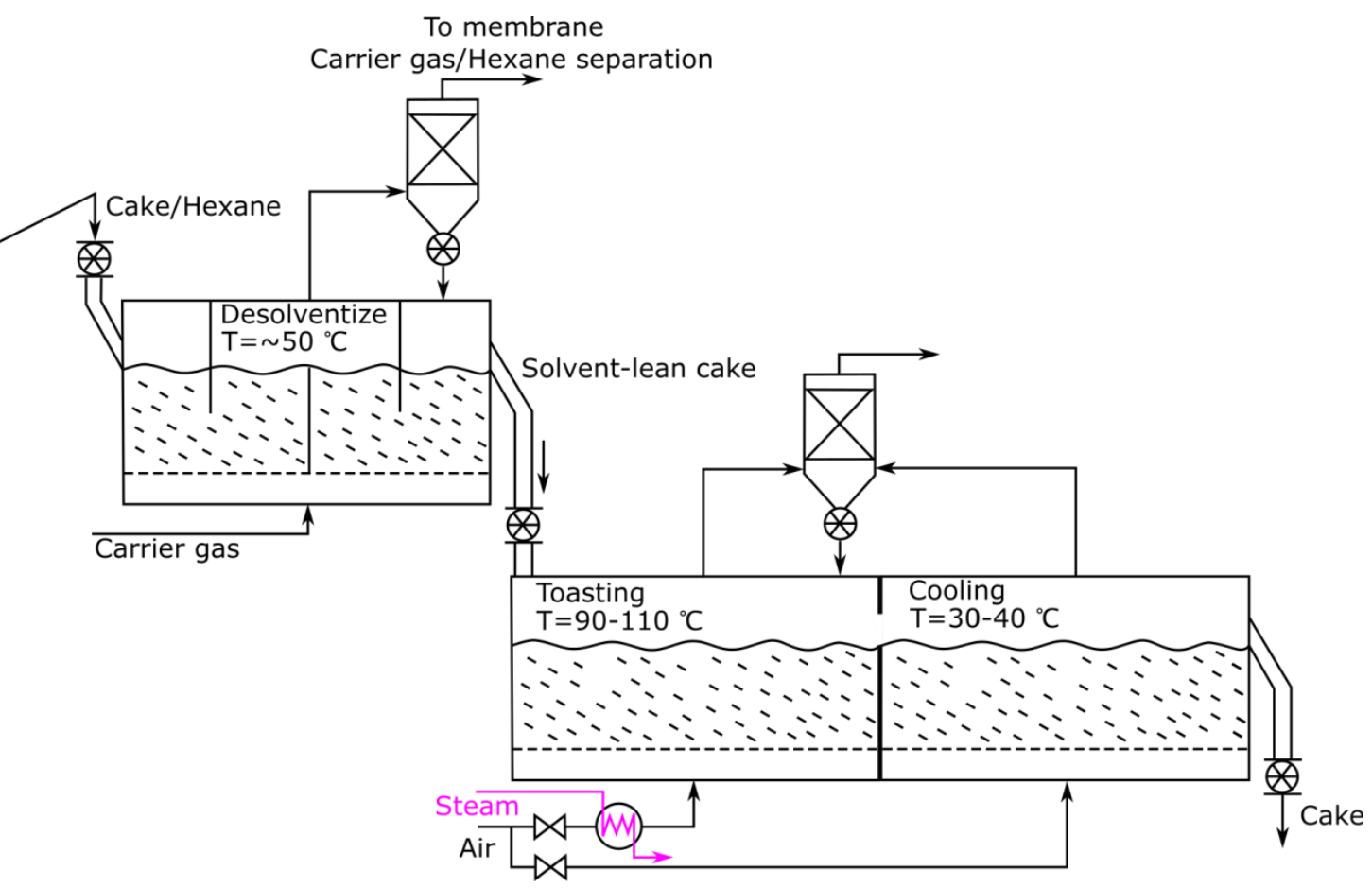

Figure 7 Design of fluidized bed desolventizer/toaster/cooler.

The cross-flow fluidized bed will consist of 3 sections, being the desolventizing section operated with $\mathrm{N}_{2}$ as fluidizing gas, and the toaster/cooler sections operated with air. Baghouse filters are installed for dust abatement. The possibility to use $\mathrm{O}_{2}$-lean carrier gas, as a mixture of air and $\mathrm{N}_{2}$ is further discussed after having established the volumetric ratio of hexane and carrier gas, and considering the explosion hazards of hexane/air mixtures.

As soybeans consist for $71 \%$ of solids, extraction of the oil leaves a solid residue. For the extraction of $10,000 \mathrm{~kg} / \mathrm{h} \mathrm{SBO}$, a residual solid stream of $35,500 \mathrm{~kg} / \mathrm{h}$ is produced. It contains 35 $w t \%$ of hexane after the extraction process. The total mass of the feed can be calculated by the simple mass balance.

$$
0.35 \times m_{\text {tot }}+m_{\text {solid }}=m_{\text {tot }}
$$

The total mass of the feed is therefore $54,615 \mathrm{~kg} / \mathrm{h}$ containing hexane, $\mathrm{m}_{\text {hex }}$, equal to 19115 $\mathrm{kg} / \mathrm{h} . \mathrm{m}_{\text {hex }}$ is used to calculate the necessary heat requirements for the fluidized bed. Before the total heat requirement of the bed can be calculated, the mass flow rate of nitrogen should be determined. Knowing that using nitrogen gas alters the partial pressure of hexane, three separate mass percentages can be found in Figure 6 for temperatures of 30,40 and $50{ }^{\circ} \mathrm{C}$ respectively, all values chosen between the dew point at $50{ }^{\circ} \mathrm{C}$ and the experimental result. (Kong et al., 2018) The 
necessary mass flow rate of nitrogen gas is determined using the equation below:

$$
m_{N 2}=\frac{m_{\text {hex }} \times w t \%_{N 2}}{\left(1-w t \%_{N 2}\right) \times 3600}
$$

\begin{tabular}{ccccc}
\hline $\mathrm{T}\left({ }^{\circ} \mathrm{C}\right)$ & $\mathrm{Wt} \%$ of $\mathrm{N}_{2}$ & $\mathbf{m}_{\boldsymbol{N} 2}(\mathrm{~kg} / \mathrm{s})$ & $\boldsymbol{v}_{\boldsymbol{N} 2}\left(\mathrm{~m}^{3} / \mathrm{s}\right)$ & $Q(\mathrm{~kW})$ \\
\hline 30 & 42.6 & 3.94 & 3.49 & 1,873 \\
40 & 32.5 & 2.56 & 2.34 & 1,831 \\
50 & 22.0 & 1.50 & 1.42 & 1,799 \\
\hline
\end{tabular}

Then the heat required in desolventizer/toaster is established.

$$
\begin{aligned}
\text { heat required }= & \text { heat for evaporatation of heaxane }+ \text { heating of solids } \\
& + \text { heat loss to the environment } \\
& =\text { heat provided by the internal or external heating system }+ \text { heat from } \mathrm{N}_{2}
\end{aligned}
$$

Neglecting heat losses, and with a heat of hexane evaporation of $350 \mathrm{~kJ} / \mathrm{kg}$, the heat required is determined for any selected operating temperature, e.g. between 30 to $50{ }^{\circ} \mathrm{C}$. Results are given in Table 5.

Table 5: Heat requirements of the bed for the different weight percentages of $\mathrm{N}_{2}$

To achieve this operation, a minimal flow of $1.42 \mathrm{~m}^{3} / \mathrm{s}(1.50 \mathrm{~kg} / \mathrm{s})$ of nitrogen is used at $50{ }^{\circ} \mathrm{C}$ to extract $1.85 \mathrm{~m}^{3} / \mathrm{s}(5.31 \mathrm{~kg} / \mathrm{s})$ of hexane from the bed.

Operating at $22 \mathrm{wt} \% \mathrm{~N}_{2}$ reduce the production necessity of $\mathrm{N}_{2}$ and lowers the membrane area in the subsequent hexane separation from the exhaust stream of the desolventizer. In addition, it has lower hexane losses. All leads to a reduction in capital cost. Further reduction in the process heat balance is achieved by preheating the nitrogen stream. The membrane separation module is discussed below.

The lower (LEL) and Upper (UEL) explosion limits in air are 1.2 and 7.4 vol\%, respectively. Since the exhaust of the desolventizer contains over $50 \%$ vol $\%$ hexane, the use of an $\mathrm{O}_{2}$-lean mixture of air and $\mathrm{N}_{2}$ could be imagined, thus further limiting the size of the $\mathrm{N}_{2}$ membrane production unit. This is however not recommended since a hexane depletion will occur in the membrane separation unit (see 4.3) and its concentration will progressively decrease and achieve values between its UEL and LUL. Since only make-up $\mathrm{N}_{2}$ is required, safe operation imposes its use throughout the desolventizing process. 


\subsection{Gas membrane separation}

For separation of the hexane- $\mathrm{N}_{2}$ mixture, a gas membrane system is applied. The membrane can guarantee high recovery of hexane for reuse in the extraction process as well as for $\mathrm{N}_{2}$ which can be reused in the fluidization process. A decrease in temperature of the gas entering the membrane system, gives a decreased efficiency of separation and thus higher losses of hexane in the process. At higher temperatures membrane swelling needs to be taken into account. Laboratory results determined the optimal performance of the membrane at $39{ }^{\circ} \mathrm{C}$ with a recovery of $96.8 \%$ of hexane. A permeability of 2,690 NL/ $\mathrm{m}^{2} \cdot h \cdot b a r$ is reached at this temperature (Degrève et al., 2001; Kong et al., 2018, 2017b).

$$
\mathrm{A}=\frac{Q_{\text {perm, hex }}}{L_{\text {hex }} \times\left(P_{\text {feed }} \times y_{\text {mean, hex }}-P_{\text {perm }} \times \frac{Q_{\text {perm,hex }}}{Q_{\text {perm,tot }}}\right)}
$$

with

$$
y_{\text {mean,hex }}=\left[\frac{Q_{\text {feed,hex }}-Q_{\text {perm,hex }}}{Q_{\text {feed,tot }}-Q_{\text {perm,tot }}}+\frac{Q_{\text {feed,hex }}}{Q_{\text {feed,tot }}}\right] / 2
$$

Equation 6 is used to determine the total area of membranes necessary to separate the $\mathrm{N}_{2}$-hexane gas mixture. The selectivity, separation factor and the intrinsic hexane permeability of the membrane can be found in Kong et al. (Kong et al., 2018) The amount of $\mathrm{N}_{2}$ and hexane on the permeate/retentate side can be calculated.

$$
\begin{gathered}
Q_{\text {feed,hex }}=\frac{m_{\text {feed,hex }}}{\rho_{\text {hex }}}=716 \mathrm{Nm}^{3} / \mathrm{h} \\
Q_{\text {feed,tot }}=\frac{m_{\text {feed,hex }}}{\rho_{\text {hex }}}+\frac{m_{\text {feed,N2 }}}{\rho_{N 2}}=1966 \mathrm{Nm}^{3} / \mathrm{h} \\
Q_{\text {perm,hex }}=\frac{m_{\text {perm,hex }} \times W t_{\text {perm, hex }}}{\rho_{\text {hex }}}=693 \mathrm{Nm}^{3} / \mathrm{h}
\end{gathered}
$$

Before the total volumetric flowrate at the permeate side can be determined, the amount of $\mathrm{N}_{2}$ at the permeate side has to be calculated.

$$
n_{\text {perm, }, N 2}=\frac{n_{\text {perm, hex }} \times y_{\text {feed,N2 }}}{y_{\text {feed, hex }} \times \beta}
$$

For the total calculated volumetric flowrate of hexane on the permeate and feed side, the membrane area is $1412 \mathrm{~m}^{2}$. A permeate pressure of $1000 \mathrm{~Pa}$ was chosen because it gives the highest membrane area necessary for separation (worst case scenario). The permeate stream is consecutively send to a cooler for further condensation. Condensed hexane can then be reused in the leaching process. The high purity $\mathrm{N}_{2}$ retentate is reused in the fluidized bed desolventizer. By 
subtracting the recovered amount of $\mathrm{N}_{2}$ by the total amount necessary of the fluidized bed, the total production quantity of $\mathrm{N}_{2}$ necessary for operation can be determined. This helps in choosing the most adequate production technique for the make-up $\mathrm{N}_{2}$.

It should moreover be remembered that a higher degree of separation is obtained in a membrane cascade. In gas permeation application, where the permeate stream of module 1 has to be compressed before feeding module 2, the cascade is often limited to 2 stages. The higher separation efficiency is certainly favored in the hexane/ $\mathrm{N}_{2}$ case, facilitating the recovery and re-use of both separate streams, although gas processing costs must be optimized (Ahsan and Hussain, 2016; Aliaga-Vicente et al., 2017; Pathare and Agrawal, 2010). The total flowsheet of Figure 8 includes the cascade membrane module.

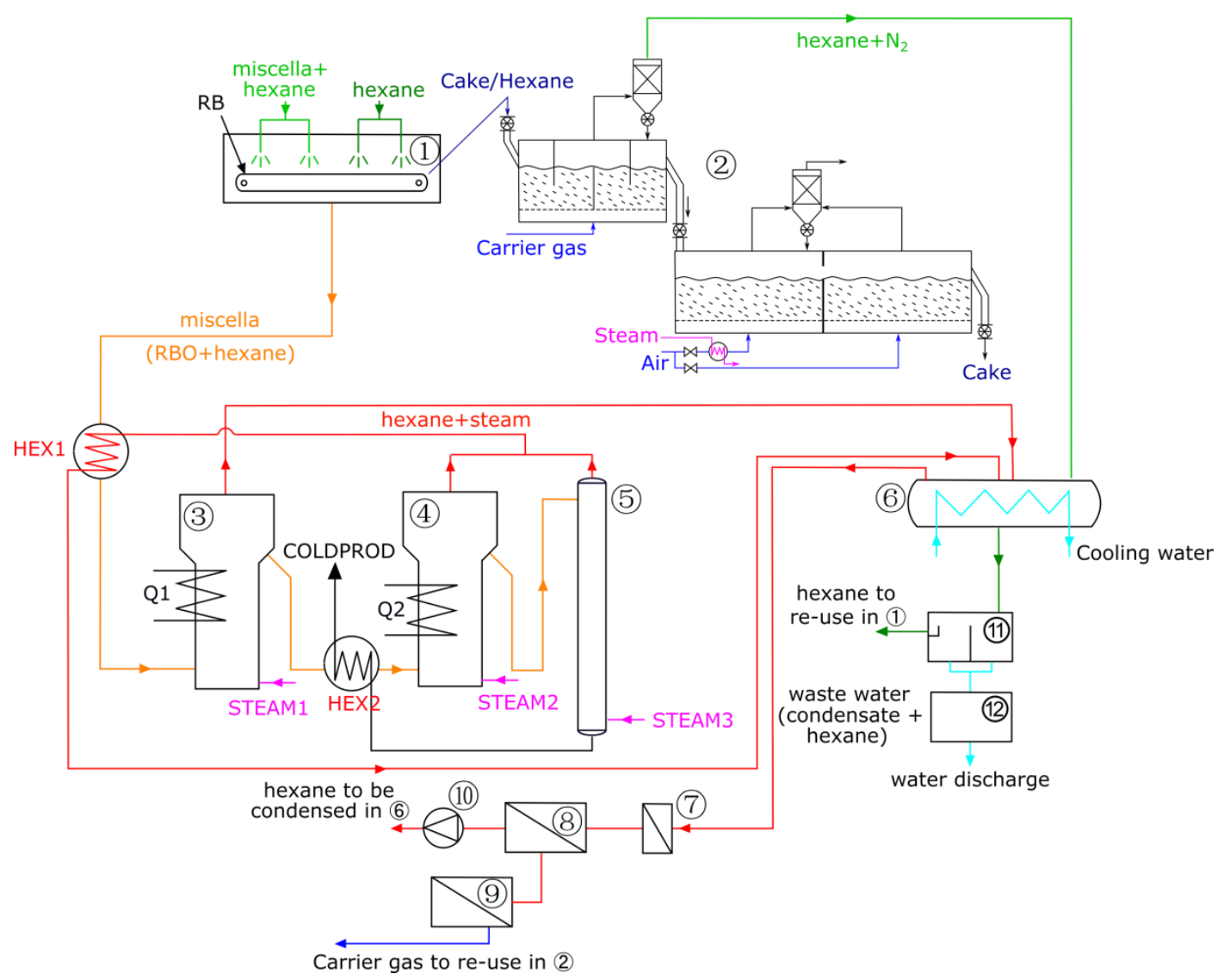

Figure 8 Detailed flow sheet of the entire production process of SBO: 1. Leaching; 2. Fluidized bed desolventizer/toaster/cooler; 3. EVAP1; 4. EVAP2; 5. STRIP; 6. Condenser; 7. Filter; 8. 
The flowsheet of Figure 8 includes the proposed improvements, and should be compared

403

\begin{tabular}{c|c|c}
\hline & Conventional SBO (MW) & Improved SBO process \\
\hline Leaching & 0.17 & 0.17 \\
Evaporators & 6.44 & 5.05 \\
Stripping & 0.18 & 0.18 \\
Desolventizer & 8.15 & 2.12 \\
Tail gas stripper & 2.93 & - \\
\hline Total & 17.87 & 7.52 \\
\hline
\end{tabular}
with the conventional process of Figure 1 . The addition of the heat exchanger network, and the implementation of a N2-driven desolventizer with gas membrane separation and reuse of hexane contribute to considerable energy and environmental benefits, as explained before.

\section{ENERGY AND ENVIRONTAL IMPACTS OF THE IMPROVED PROCESS}

The previous sections calculated the net amounts of live steam injection and closed circuit (indirect) steam uses. To convert them to operational values including the boiler efficiency (85\%), gross energy inputs are obtained.

The comparative energy picture is illustrated in Table 6.

Table 6 Conventional energy consumption in SBO process (at $85 \%$ boiler efficiency)
413

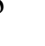
The electricity consumption in the crude oil extraction processes is on average $125 \mathrm{~kW} /$ ton of crude oil (Kong et al., 2018). It is not expected that major reductions are achieved since the reduction through a lower boiler capacity will be outbalanced by the required power for fluidization and gas membrane separation. A 10 ton/h SBO plant will hence consume about 1.25 MW of electric power.

Based upon these energy figures and their equivalent $\mathrm{CO}_{2}$ emission potential, it is clear that the improved SBO process will have a lower $\mathrm{CO}_{2}$ footprint than the conventional process. For the conventional process, $\mathrm{CO}_{2}$ emissions are calculated at 506,000 ton/year against 189,570 ton/year for the improved process. A reduction of $62.5 \%$ of $\mathrm{CO}_{2}$ emission is achieved.

The waste water discharge is mostly determined by the steam condensate. The steam 
condensate has an average COD-load of $\sim 4.6 \mathrm{~g} / \mathrm{L}$, an average concentration of soap, oils and grease of $630 \mathrm{mg} / \mathrm{L}$, and an aerobic activated sludge treatment. Reverse osmosis is being introduced to reduce sulphate contents (Cheng et al., 2018). Due to the reduction of direct steam injection in the process from 620 to $270 \mathrm{~kg} / \mathrm{h}$, the water treatment plant will see a $56.5 \%$ reduction in hydraulic and pollutant loads.

\section{CONCLUSIONS}

The entire improved process was displayed in Figure 8. By designing a new configuration for the evaporator-stripper part of the process, the live steam usage is reduced from $620 \mathrm{~kg} / \mathrm{h}$ to 270 $\mathrm{kg} / \mathrm{h}$, and the total heat duty is reduced by $21.9 \%$. The original desolventization process required an energy input of $8.15 \mathrm{MW}$. At $100 \%$ heat recovery, the application of the fluidized bed desolventization with preheating of nitrogen reduces this requirement to $2.12 \mathrm{MW}$ which results in a saving of $74 \%$. The improvements moreover reduce both the waste water loadings by $56.6 \%$ and the $\mathrm{CO}_{2}$ emissions by $62.5 \%$. Hexane emissions are moreover significantly reduced by over $90 \%$.

\section{ACKNOWLEDGEMENT}

This work was supported by the National Basic Research Program of China (973 program) (2013CB733600), by "the Fundamental Research Fund for the Central Universities (JD1717, ZY1714) and (buctrc201726), and by the Beijing Advanced Innovation Center for Soft Matter Science and Engineering of the Beijing University of Chemical Technology.

\section{References}

Ahsan, M., Hussain, A., 2016. Mathematical modelling of membrane gas separation using the finite difference method. Pacific Sci. Rev. A Nat. Sci. Eng. 18, 47-52. https://doi.org/10.1016/J.PSRA.2016.07.001

Alam, M., Akram, D., Sharmin, E., Zafar, F., Ahmad, S., 2014. Vegetable oil based eco-friendly coating materials: A review article. Arab. J. Chem. 7, 469-479. https://doi.org/10.1016/J.ARABJC.2013.12.023

Aliaga-Vicente, A., Caballero, J.A., Fernández-Torres, M.J., 2017. Synthesis and optimization of membrane cascade for gas separation via mixed-integer nonlinear programming. AIChE J. 63, 
1989-2006. https://doi.org/10.1002/aic.15631

Cargill, n.d. Palm Kernal Oils - Fats and Oils - Asia Pacific [WWW Document]. URL https://www.cargill.com/food-bev/ap/palm-kernel-oils (accessed 1.13.18).

Carrín, M.E., Crapiste, G.H., 2008. Mathematical modeling of vegetable oil-solvent extraction in a multistage horizontal extractor. J. Food Eng. 85, 418-425. https://doi.org/10.1016/J.JFOODENG.2007.08.003

Cerutti, M.L.M.N., de Souza, A.A.U., de Souza, S.M.D.A., 2012. Solvent extraction of vegetable oils: Numerical and experimental study. Food Bioprod. Process. 90, 199-204. https://doi.org/10.1016/J.FBP.2011.03.002

Cheng, M.-H., Sekhon, J.J.K., Rosentrater, K.A., Wang, T., Jung, S., Johnson, L.A., 2018. Environmental impact assessment of soybean oil production: Extruding-expelling process, hexane extraction and aqueous extraction. Food Bioprod. Process. 108, 58-68.

Degrève, J., Everaert, K., Baeyens, J., 2001. The use of gas membranes for VOC-air separations. Filtr. Sep. 38, 48-54. https://doi.org/10.1016/S0015-1882(01)80295-0

Erickson, D.R., 1995. Practical handbook of soybean processing and utilization. AOCS Press.

Issariyakul, T., Dalai, A.K., 2014. Biodiesel from vegetable oils. Renew. Sustain. Energy Rev. 31, $446-471$

Kong, W., Baeyens, J., Qin, P., Zhang, H., Tan, T., 2018. Towards an energy-friendly and cleaner solvent-extraction of vegetable oil. J. Environ. Manage. 217, 196-206. https://doi.org/10.1016/J.JENVMAN.2018.03.061

Kong, W., Kang, Q., Feng, W., Tan, T., 2015a. Improving the solvent-extraction process of rice bran oil. Chem. Eng. Res. Des. 104, 1-10. https://doi.org/10.1016/j.cherd.2015.06.001

Kong, W., Kang, Q., Feng, W., Tan, T., 2015b. Improving the solvent-extraction process of rice bran oil. Chem. Eng. Res. Des. 104, 1-10. https://doi.org/10.1016/j.cherd.2015.06.001

Kong, W., Miao, Q., Qin, P., Baeyens, J., Tan, T., 2017a. Environmental and economic assessment of vegetable oil production using membrane separation and vapor recompression. Front. Chem. Sci. Eng. 11, 166-176. https://doi.org/10.1007/s11705-017-1616-4

Kong, W., Miao, Q., Qin, P., Baeyens, J., Tan, T., 2017b. Environmental and economic assessment of vegetable oil production using membrane separation and vapor recompression. Front. Chem. Sci. Eng. 11, 166-176. https://doi.org/10.1007/s11705-017-1616-4 
Lin, L., Ying, D., Chaitep, S., Vittayapadung, S., 2009. Biodiesel production from crude rice bran oil and properties as fuel. Appl. Energy 86, 681-688.

Martinho, A., Matos, H.A., Gani, R., Sarup, B., Youngreen, W., 2008. Modelling and simulation of vegetable oil processes. Food Bioprod. Process. 86, 87-95.

Ong, T.L., 1984. Energy saving in the soybean extraction industry by reducing the steam consumption for desolventizing-toasting and drying extracted beans.

Pathare, R., Agrawal, R., 2010. Design of membrane cascades for gas separation. J. Memb. Sci. 364, 263-277. https://doi.org/10.1016/J.MEMSCI.2010.08.029

Spirax Sarco, 2018. Steam table calculator [WWW Document]. URL http://www2.spiraxsarco.com/esc/SS_Properties.aspx?lang_id=ENG\&country_id=\%0AUS (accessed 4.17.18).

Wang, M., Nie, K., Cao, H., Xu, H., Fang, Y., Tan, T., Baeyens, J., Liu, L., 2017. Biosynthesis of medium chain length alkanes for bio-aviation fuel by metabolic engineered Escherichia coli. Bioresour. Technol. 239, 542-545. https://doi.org/10.1016/J.BIORTECH.2017.05.101

Yun, H., Wang, M., Feng, W., Tan, T., 2013. Process simulation and energy optimization of the enzyme-catalyzed biodiesel production. Energy 54, 84-96. 
(a)

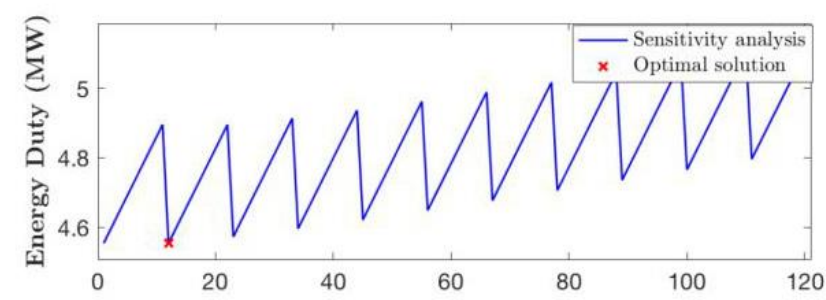

(b)

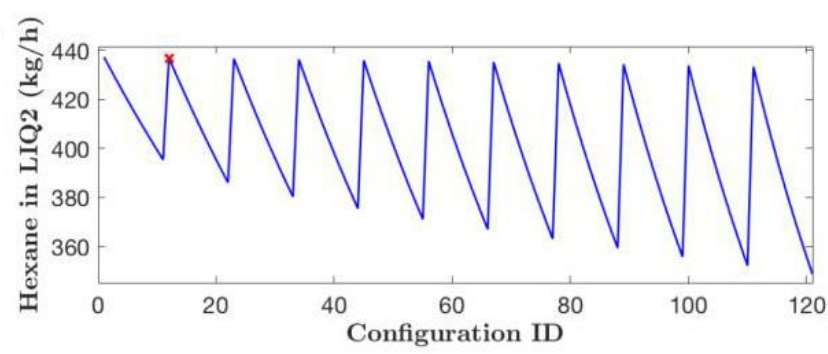

505

Figure A1 Set-up with one heat exchanger (a) Energy required for different configurations (b).

(a)

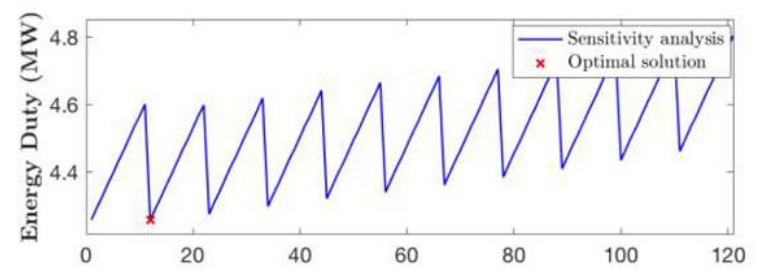

(b)

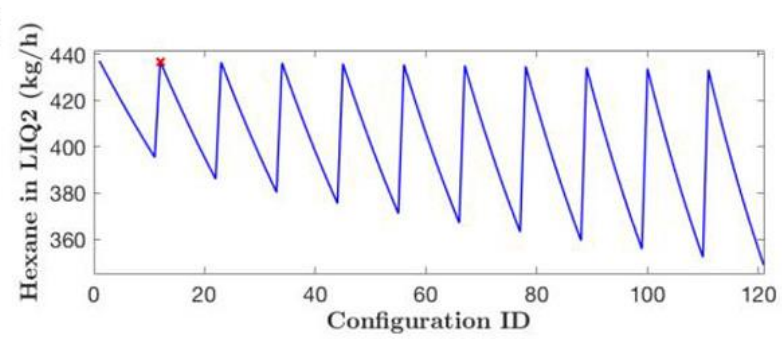

Figure A2 Set-up with two heat exchangers, option A (a) Energy required for different configurations (b) Hexane remaining in liquid outflow of 2nd evaporator for different 
(a)

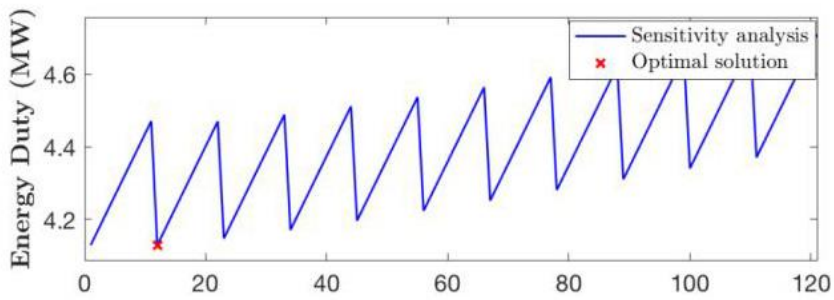

(b)

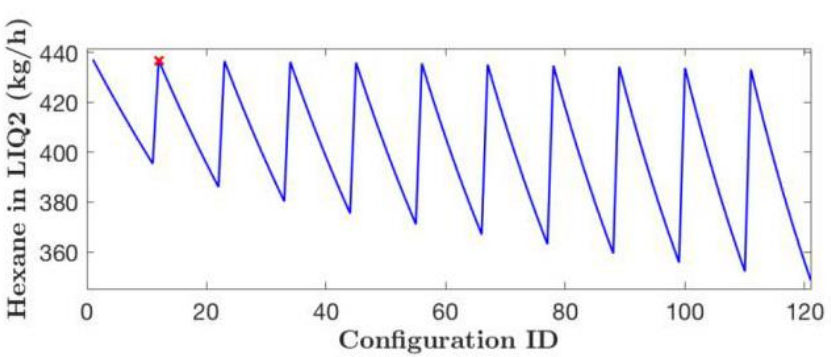

Figure A3 Set-up with two heat exchangers, option B (a) Energy required for different configurations (b) Hexane remaining in liquid outflow of 2nd evaporator for different configurations 